\title{
POLICY ANALYSIS OF MANGO'S AGRIBUSINESS DEVELOPMENT (A CASE IN CIKEDUNG DISTRICT, INDRAMAYU REGENCY)
}

\author{
Elly Rasmikayati*)1, Ellisa Agri Elfadina*), Rani Andriani Budi Kusumo*), \\ Bobby Rachmat Saefudin ${ }^{* *}$, and Supriyadi***) \\ ${ }^{*}$ Faculty of Agriculture, Padjadjaran University \\ Jl. Bandung-Sumedang KM.21, Jatinangor, 45363, Indonesia \\ ${ }^{* *}$ Faculty of Agriculture, Ma'soem University \\ Jl. Raya Cipacing No.22, Jatinangor, 45363, Indonesia \\ $\left.{ }^{* * *}\right)$ Faculty of Agriculture, Universitas Wiralodra \\ Jl. Ir. H Djuanda KM.03, Karanganyar, 45213, Indonesia
}

\begin{abstract}
Mango is a popular commodity with local demand and exports are quite high each year. However, there is a fluctuation of land tenure area and the number of mango trees in Cikedung district, Indramayu regency that can affect the quantity of mango produced by farmers. This study aims to analyze the policies that have been carried out by the Ministry of Agriculture of the Republic of Indonesia related to the development of mango agribusiness and compile policy recommendations for developing mango agribusiness in Cikedung District, Indramayu Regency. The method used in this research is a survey method to 130 respondents. Data analyzed using the descriptive statistics analysis and Tinbergen model. The results showed that the type of government policies that has been accepted by some mango farmers in Cikedung district is very limited, the only grant of mango seed. The development of mango agribusiness policy that can be used to increase the land tenure area so that it impacts on increasing quantity of mango harvest, namely grant of agricultural production, land lease, seed grant, price subsidy of agricultural production facilities, and capital loans.
\end{abstract}

Keywords: policy analysis, agribusiness development, mango farming, land area, Tinbergen model

\begin{abstract}
Abstrak: Mangga merupakan komoditas populer dengan permintaan lokal dan ekspor yang cukup tinggi setiap tahunnya. Namun, terjadinya fluktuasi penguasaan luas lahan dan jumlah pohon mangga di Kecamatan Cikedung, Kabupaten Indramayu dapat mempengaruhi produksi mangga yang dihasilkan oleh petani. Penelitian ini bertujuan menganalisis kebijakan yang sudah dilakukan oleh Kementerian Pertanian Republik Indonesia terkait pengembangan agribisnis mangga dan menyusun saran kebijakan untuk mengembangkan agribisnis mangga di Kecamatan Cikedung, Kabupaten Indramayu. Metode yang digunakan dalam penelitian ini adalah metode survei terhadap 130 responden petani mangga. Data dianalisis menggunakan statistik deskriptif dan model Tinbergen. Hasil penelitian menunjukkan bentuk kebijakan pemerintah yang pernah diterima oleh sebagian petani mangga di Kecamatan Cikedung sangat terbatas yakni hanya berupa hibah bibit mangga. Kebijakan pengembangan agribisnis mangga yang dapat dilakukan untuk meningkatkan luas penguasaan lahan sehingga berdampak pada peningkatan kuantitas hasil panen mangga yakni hibah sarana produksi pertanian, sewa lahan, hibah bibit, subsidi harga saprotan, serta pinjaman modal.
\end{abstract}

Kata kunci: analisis kebijakan, pengembangan agrobisnis, usahatani mangga, luas lahan, model Tinbergen

\footnotetext{
${ }^{1}$ Corresponding author:

Email: e.rasmikayati@unpad.ac.id
} 


\section{INTRODUCTION}

Mango is a famous and exotic commodity that is produced by almost all regions in Indonesia with different quality and quantity. Mango is also identified as one of the fruit commodities that have the highest comparative and competitive advantage in the world (Pradipta and Firdaus, 2014).

There are five central provinces in Indonesia which are mango producers namely East Java, Central Java, West Java, South Sulawesi, and West Nusa Tenggara (BPS, 2017). Although West Java Province only ranks third as a mango producer in Indonesia, it has several advantages over other provinces. These advantages are having the highest average productivity for five years with 11.7 tons/ha while East Java and Central Java have only the productivity of 9.5 tons/ha and 10.5 tons/ ha, respectively. In addition, diversification of superior mango varieties in West Java as well as certified mango crop seed production is higher than East Java and Central Java Provinces.

The government of West Java Province is collaborating with the Government of Japan in international trade of Gedong Gincu mango due to high demand of Japanese people for mangoes from West Java. Mango-producing areas in West Java are spread in 27 districts and cities of wich five districts as production centers i.e, Indramayu, Cirebon, Majalengka, Kuningan and Sumedang. They cultivated various types of mangoes including Gedong Gincu, Gedong, Arumanis, Golek, and Dermayu.
However, the problem is that the area of mango cultivated in West Java during 2012 and 2016 fluctuateds. A significant increase in mango harvested area occurred in $2013-2014$ by $11 \%$ while a drastic decrease occurred in $2014-2015$ by $30 \%$ (Figure 1).Therefore, the numbers of harvested area was not as expected.

Indramayu Regency as the main production center in West Java which makes mangoes as the identity of the region produces the amount of mango production which also fluctuates. Within a period of five years, Indramayu Regency achieved the most mango production in 2016 with 9,064 tons while in 2012 it only reached 6,851 tons (BPS Kabupaten Indramayu, 2017).

There are six districts which are the centers of mango production in Indramayu Regency, namely Haurgeulis, Kroya, Cikedung, Gantar, Sliyeg, and Jatibarang. In the period of five years, Haurgeulis District achieved the most production in 2014 of 3,360 tons and the amount of production decreased dramatically in 2016 to 210 tons. In 2012, Kroya District produced 1,600 tons of mangoes. However, the production has continued to decline to 103 tons in 2016. Likewise with the four other districts, fluctuation amounts of production affects the availability of local mangoes (BPS Kabupaten Indramayu, 2017).

Cikedung district faces fluctuations in production and and land area as well as the number of mango trees. The number of mango trees increased the highest in 2013-3014 by 30\%, while the number of mango trees decreased significantly in $2014-2015$ by $36 \%$ (Table $1)$.

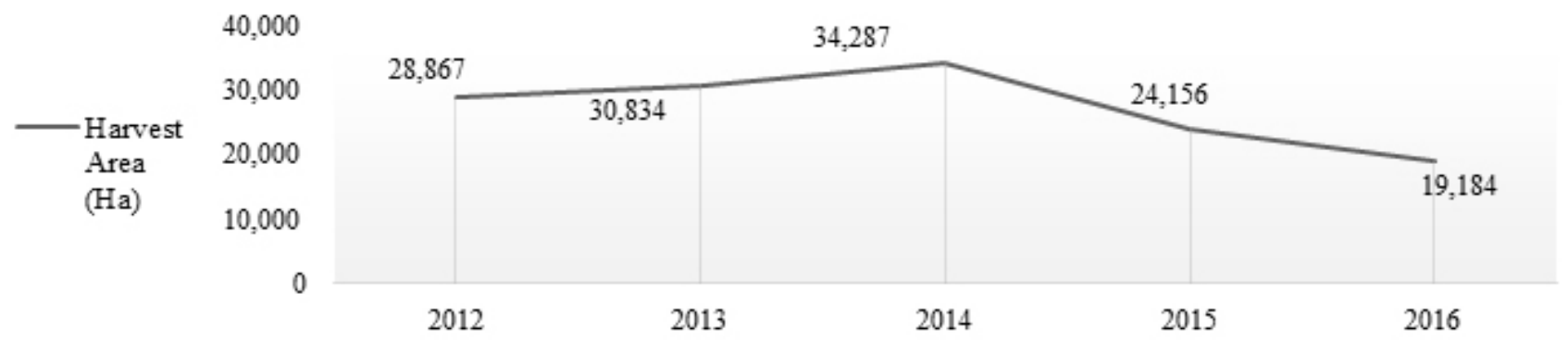

Figure 1. Mango Harvest Area (Ha) in West Java 2012 - 2016 (BPS, 2017) 
Table 1. Number of Mango Trees by Sentra District in Indramayu Regency

\begin{tabular}{|c|c|c|c|c|c|c|}
\hline \multirow{2}{*}{ Districts } & \multicolumn{5}{|c|}{ Year } & \multirow{2}{*}{ Share $(\%)$} \\
\hline & 2012 & 2013 & 2014 & 2015 & 2016 & \\
\hline Haurgeulis & 74.346 & 74.256 & 297.384 & 81.746 & 63.100 & 17 \\
\hline Gantar & 37.990 & 37.990 & 75.980 & 37.990 & 36.155 & 7 \\
\hline Kroya & 46.300 & 45.273 & 43.973 & 11.728 & 40.393 & 5 \\
\hline Cikedung & 39.785 & 48.799 & 69.770 & 44.309 & 46.517 & 7 \\
\hline Sliyeg & 16.188 & 37.682 & 60.250 & 28.426 & 22.026 & 5 \\
\hline Jatibarang & 38.494 & 46.780 & 58.320 & 48.032 & 52.264 & 7 \\
\hline Total & 253.103 & 290.780 & 605.677 & 252.231 & 260.455 & 48 \\
\hline Indramayu Regency & 577.865 & 660.147 & 1.153 .176 & 491.494 & 575.234 & 100 \\
\hline
\end{tabular}

Description : Share (ratio of total production per district to total production per regency)(BPS of Indramayu Regency, 2017)

Decreasing the number of trees owned by farmers will affect their income and production, thus negatively impacting their welfare. In addition, the average mango farmer in Cikedung District already has quite a long experience of mango farming. This, of course, can be an initial capital for farmers to develop mango farming by increasing the number of mango trees cultivated. Nevertheless, the number of farmers' mango trees fluctuates and years in experience does not guarantee the stability and development of mango farming.

The overall dynamics of agribusiness of mango farmers in Cikedung District cannot be separated from government policies in the development of mango agribusiness, especially in the field of land. There are many factors that can influence the development of mango agribusiness including social, economic, technological, resource, institutional and cultural (Rasmikayati and Saefudin, 2018). Mango agribusiness in the Cikedung district has several potential and opportunities including natural conditions and weather that are very suitable for mango cultivation, mangoes as a city brand of the Regency of Indramayu, ease in cultivation techniques for farmers due to hereditary mango farming, as well as profitable yields and can increase family income farmers. Therefore, the policies are needed to strictly regulate the development of mango agribusiness for farmers both in terms of the application of cultivation techniques according to the SOP, the determination of the sale price of mangoes, to land tenure. According to Friyatno and Saptana (2017) related to the importance of developing integrated agribusiness from the bottom up. It is intended that mango production in Indramayu Regency, especially in production centers, remains stable and can meet local and export market demands and improve farmers' welfare.
Farizal (2015) revealed that government policies in increasing the competitiveness of Gedong Gincu mango farming have been applied both to inputs and outputs, including, (a) VAT policy of $10 \%$ on production inputs such as equipment, fertilizers, and medicines , (b) import tax increase policy of $5 \%$ on agricultural raw material products such as fertilizers and medicines, (c) allocation of subsidized fertilizer, (d) policy on closing tap of horticultural products imports that have not been effective in increasing the competitiveness of farming systems of superior fruit commodities West Java.

However, the problem is that government policies related to mango plants are very limited and inversely proportional to policies, programs, and government assistance regarding various food commodities. The government has contributed through the raising of SOP (Standard Operational Procedure) in 2006 and 2009 to mango farmers in the form of an explanation of environmental friendly technologies, pest control, plant rejuvenation, cultivation, cmango harvesting techniques. The government also conducted tree rejuvenation by supply of mango seedlings about 2000 tress and 7,000 in 2009 and 2013, respectly. The mango seedlings distributed to several districts in Indramayu Regency. Cikpapan district is one of the districts that received mango seedlings consists of Gedong Gincu and Lalijiwo. The rejuvenation is allocated into areas that have mango plantations in which its distribution depends on potential in each area (Alviary, 2013). Furthermore, in the future, Center of group for mango species will be held (Alviany, 2013). In addition, Australian Center for International Agricultural Research (ACIAR) provided both rehabilitation and fly pest management program from 2010 to2014 (Pratiwi, 2013). 
Farmers are facing high price of mango cultivation technology and limited of capital. Moreover, the attack of pests and diseases can not be minimized so that affected to decrease both quantity and qualtity of mangoes. As a result, the government policies were inadequate to improve mangoes productivity. The limited government policies in the horticulture, particularly in mango may indicate that agricultural development is not optimal yet. . This study aims to analyze the government policies related to the development of mango agribusiness and draw up policy recommendations for developing mango agribusiness in Cikedung District, Indramayu Regency.

\section{METHODS}

The object of this research is the government policy related to the development of mango agribusiness in the District of Cikedung, Indramayu Regency in 2019. The design used in this study is quantitative research with survey methods. The sampling technique used in this study is the simple random sampling technique with a total samples of 130 people.

The limitations of government policies related to mango agribusiness in Cikedung district will be seen based on the crosstab analysis tool and the Tinbergen model framework. In descriptive statistical analysis will be explained and described government policies both in the form of material and concrete actions such as counseling. Meanwhile, the Tinbergen model policy will simulate a number of possible government policies and describe the variables related to inhibiting factors and interactions that occur to achieve the final goal in the form of an increase in mastery of farmers' mango land in the District of Cikedung.

Tinbergen's policy theory (Tinbergen Policy "analysis framework policy") (Figure 2) was used to analyze mango agribusiness development policies This method aims to achieve social welfare by conducting an analysis that will lead to creation of a policy. In accordance with this theory, achieving these objectives must be analyzed what are the endogenous variables (objectives) and exogenous variables consisting of policy instruments to deal with constraints and factors beyond human control (beyond control) in its implementation. The three exogenous variables will affect not only the goal but also further create side effects.In this study, the Tinbergen model policy was not intended to deliver the creation of policy designs so as to achieve social welfare. However, it was used as a policy simulation in the form of the possibility that will occur if there are government policies related to the development of mango agribusiness in the district or central district. Output of policy simulation would be type of recommendation to increase manggo land cultivated by farmers.

The relationship between exogenous and endogenous variables was explained through crosstab analysis. In Tinbergen's policy analysis, policy instruments were grouped into exogenous variables while goals and side effects were classified into endogenous variables.

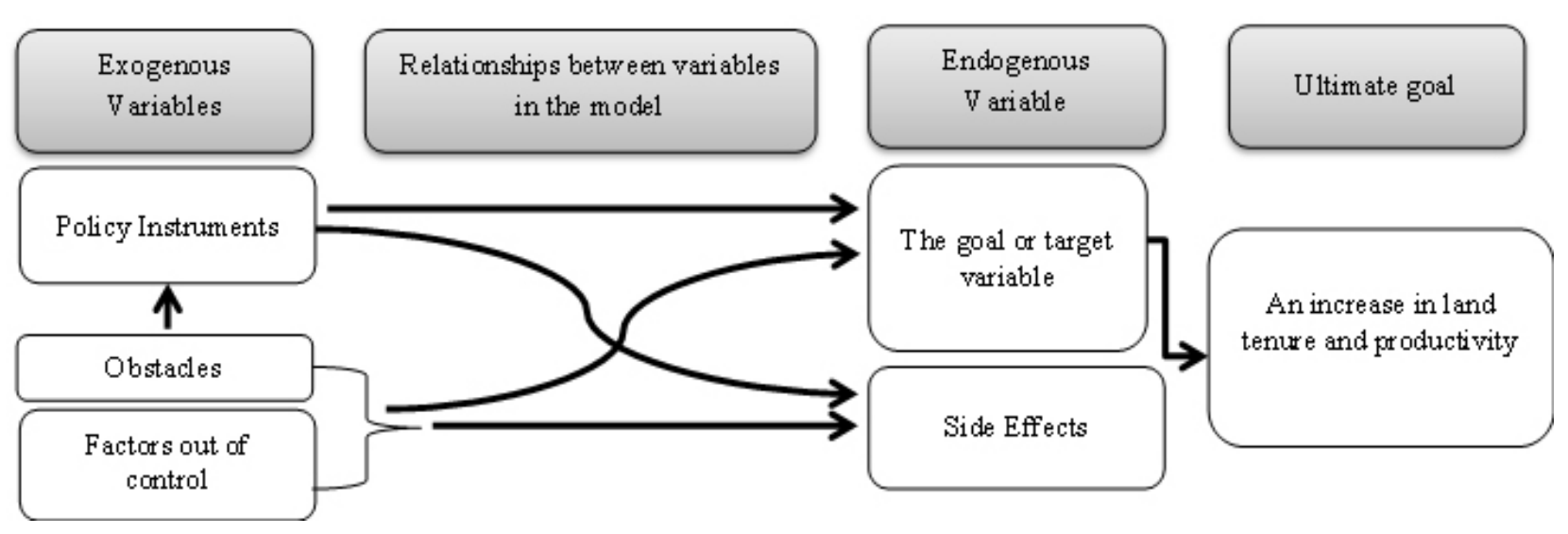

Figure 2. Tinbergen's Model Policy Framework on Mango Agribusiness Development ( Ellis (1992) in Sembiring, 2011). 


\section{RESULTS}

\section{Government Policies Regarding Horticulture, Land and Mango}

According to Indrafachrudi in Rachmat (2016) policy is a basic provision that becomes the basis and direction in carrying out administrative or management activities. While Mustopadidjaja in Rachmat (2016) argues that policy is the decision of an organization that is intended to overcome certain problems as a decision or to achieve certain goals, containing provisions that can be used as guidelines for behavior in (1) further decision making must be done either the target group or organizational unit implementing the policy; (2) the application or implementation of a policy that has been determined both in relation to the implementing organizational unit or with the intended target group.

The regional autonomy policy is part of the national government policy. One of the aspects of regional autonomy policy is the presence of local government authority (regency) in managing the potential of local area resources (Hapsari et al. 2019). This condition is one of the opportunities to increase mango farming as a leading commodity in the area concerned. However, there is a need for commitment, rules or policies that support efforts in that direction so that activities can run optimally.

Mango is one of Indonesia's export commodities that is directly in contact with international trade which is competitive. However, the limitations of technology owned by farmers can cause competition in the liberalization of this commodity or the era of economic globalization (Kusumo et al. 2018). Operational steps that can be taken in the development of mango agribusiness is to actively involve the participation of several stakeholders (stakeholders) as the central or focus of activities, local governments, banking institutions, NGOs, traders/companies, and exporters (Iqbal and Dalimi, 2006 ). In addition, the role of the central government is also needed in the development of mango agribusiness, one of which is by issuing several written regulations/policies.

Here are some policies/regulations made by the government relating to horticultural commodities and mangoes in particular, including:

a. Number 61/Permentan/OT.160/11/2006 Concerning

Good Fruit Cultivation Guidelines (GAP). This regulation aims to 1) Increase the production and productivity of fruit plants; 2) Improving the quality of fruit, including the safety of fruit consumption; 3 ) Increase production efficiency and competitiveness of fruit plants; 4) Improve the ethical use of natural resources; 5) Maintaining the fertility of land environmental sustainability and sustainable production systems; 6) Encourage farmers and farmer groups to have a responsible mental attitude towards products produced in health and self-safety and the environment; 7) Increase competitiveness and opportunities for discovery by international and domestic markets; and 8) Providing security guarantees to consumers. The scope of this regulation provides fairly comprehensive standard operational procedures including land, use of seeds and plant varieties, naming, fertilizing, crop protection, irrigation, crop management / maintenance, harvesting, post-harvest handling, agricultural tools and machinery, environmental preservation, labor work, cleaning facilities, landfills, registration of supervisors and reverse search, certification and guidance.

b. Number 570/Kpts/SR.120/9/2006 concerning the Release of Mango of Darakande as a superior variety. In the decree, the government released the Darakande mango as a superior variety that has advantages, especially in its production which can reach $200-500 \mathrm{~kg} /$ tree / year and adapts well in the lowlands with an altitude of 0-350 m above sea level.

c. Number 305/Kpts/SR.120/4/2006 Concerning the Release of Indramayu Cengkir Mango as a Superior Variety. In the decree, the government released the Cengkir Indramayu mango as a superior variety that has advantages, especially in its production which can reach $300-400 \mathrm{~kg} /$ tree / year and adapts well in the lowlands with an altitude of $10-200 \mathrm{~m}$ above sea level.

d. Number 495/Kpts/SR.120/12/2005 concerning the Release of Damar Mango as a Superior Variety. In the decree, the government released the Damar mango as a superior variety that has advantages in especially the flowering period in September to January which allows off season production.

e. Number 58 / Permentan /OT.140/9/2012 concerning Protection, Maintenance, Recovery, and Improvement of Horticultural Land Function. This regulation aims to increase the utilization of horticultural land through protection, maintenance, restoration and improvement of the function of 
horticultural cultivation land in a sustainable manner. The scope includes: horticultural cultivation land; horticulture cultivation land protection; maintenance of horticultural cultivation land; restoration of horticultural cultivation land; and improving the function of horticultural cultivation land.

f. Number 336/Kpts/TP.240/2/2003 concerning the Release of Podang Urang Mango as a Superior Variety. In the decree, the government released the Podang Urang mango as a superior variety that has advantages, especially in its production which can reach $460 \mathrm{~kg}$ / year and has a small Sie of seed.

g. Number 337/Kpts/TP.240/6/2003 concerning the Release of Bengkulu Mango as a Superior Variety. In the decree, the government released Bengkulu mango as a superior variety that has advantages that can bear fruit throughout the year with an average harvest of 4-5 times / year even though its production is small (118.3 $\mathrm{kg}$ per year).

\section{Analysis of Tinbergen's Policy Model Regarding Mango Agribusiness Development}

The government is an organization that has the power to make and apply laws and laws in certain areas as well as to provide aid and assistance to farmers. Referring to Elfadina et al. (2019), it is known that government policies related to horticulture, especially mangoes are still very limited. The focus of government policy tends only to food commodities and plantations.

Referring to Table 2, as many as 130 mango farmers respondents said that they had never received government grants either in the form of capital or saprotan (Agricultural Production Facilities) as well as other policies such as land rent. Farmers only use modest own costs as a source of capital for mango farming activities. Farmers were not received grants, not only grants in the form of saprotans and capital that were never received by farmers but also grants for the expansion of mango land. The unavailability of government grants as capital has a linear relationship with access to grant funds. Referring to Table 2, $88 \%$ of mango farmers with narrow, medium and large land tenure stated that the gorvenment grant funds were difficult to access, while $12 \%$ of farmers indicted quite difficult to acess. No farmers stated easily accessible.

Farmers were difficult to access grant of funds because there are many requirement that must be compeleted. Governenment is not allowed to supply grants to individual. Technically and structurally, farmers who want to obtain grants must join farmer organizations or farmer groups that are registered and have a legal entity (Azizah et al. 2019). After that, farmer groups must submit proposals to the Ministry of Agriculture through the local Agriculture Service. If the proposal has been accepted by the relevant parties, the farmer group only needs to wait for the delivery of government assistance/grants without any return agreement or so on. However, the main problem was that $97 \%$ of the respondents' mango farmers are not part of a particular farmer group so there is no possibility of being able to access grant funds (Table 2).

The limitation of government policy or assistance for mango farming in the district of Cikedung has been a problem faced by mango farmers today. The government has donated mango seedlings in 2010 and 2013 in Cikedung district, but the seeds were not good quality seeds. Farmers stated that the size of the seed received was too small, so the seed were vulnerable to damage and death. Furthermore, distribution of seedling was not on target such as some farmers did not have land to cultivate the mango received. Therefore, use of mango seedlings was not optimal.

Table 2. Access to grant funds and membership in farmer groups in terms of land tenure

\begin{tabular}{llcccc}
\hline & & \multicolumn{3}{c}{ Land Tenure } & \multirow{2}{*}{ Total (\%) } \\
\cline { 3 - 5 } & & Narrow & Medium & Large & \\
\hline Access to grant funds (\%) & Difficult & 45 & 25 & 18 & 88 \\
& Difficult enough & 4 & 7 & 1 & 12 \\
Total (\%) & & 49 & 32 & 19 & 100 \\
Incorporated in farmer groups (\%) & member & 2 & 1 & 0 & 3 \\
& no member & 47 & 31 & 19 & 97 \\
& & 49 & 32 & 19 & 100 \\
\hline
\end{tabular}


In 2014, the Agriculture Service held a training and counseling event. However the training focused on developing mango farming rather than rice. According to Elfadina et. al. (2019), limited counseling and training in mango farming due to assumptions from the local agriculture office that the manggo farmers were advanced not only in cultivation but also marketing. They have been guaranteed by collector and middlemen for a long time.

Based policy simulation, some government policies that were possible to increase the land tenure of mango consist of grant in saprotan and seed, land rent, capital loans and price subsidies of saprotan. Type of saprotan grants can be agricultural equipment and fertilizers, pesticides, and growth stimulans technology.

Although the government has already given seed grants to farmers, utilization of seed grants wasnot optimal. The seeds should be good quality in terms of age of seeds, varieties, and other physical conditions. Moreover, the supply of seedlings must consider the conditions and area of land tenure in each farrmers so seeds can use optimally. Price subsidies of saprotants included fertilizer and pesticides to increase productivity of mango trees lead to optimal yields.. The majority of farmers in this study stated that prices of fertilizers, pesticides, and ZPT were very expensive. Hence, the farmers did not carry out to preservemango trees.

Referring to the results of this study, $32 \%$ of respondents cultivated mango in the land leased $\mathrm{s}$ (Table 3). Rasmikayati and Saefudin (2018) stated that farmers who rent land indicating passionate doing farming activities. Furtherrmore, farmers who leased land may be confident to carry out farming activities properly. Thus, expanding the land controlled and cultivated will result in greater profits.Capital loans by the government can also be used asgovernment contribution and participation in the development of mango agribusiness. Availability of capital loan program is a way to maintain the existing agricultural land as well as to increase the agricultural land tenure in mango, Capital loan assistance should be able to benefit and facilitate farmers such as setting loan interest at 0 (zero) percent. However, farmers must commit and strive to use the capital borrowed for mango farming activities with the ultimate goal to increase their mango land tenure (Rasmikayati et al. 2018).According to Rasmikayati et. al. (2019), the development of mango agribusiness can be seen from several aspects including production/cultivation which includes saprotan sources, capital, and land tenure; marketing such as distribution and prices; until processing. In this research, the development of mango agribusiness only focused on land tenure aspects. Limited capital and maintenance costs owned by mango farmers per season (a year) were also one of the obstacles to increase their land tenure. Rasmikayati et al. (2017) found that the expenditure for fertilizer and medicines on mango farming in one year was $\mathrm{Rp} 2,350,000 / \mathrm{Ha}$. Hence, if the majority of farmers cultivate mango land with an area of 0.5 hectares, the total expenditure per year was Rp1,175,000.

Mango farmers in this study only have an average capital of one year less than Rp1,000,000/0.5 Ha.Moreover, some farmers did not have capital to spend for fertilization and other mango maintenance activities. In essence, the extension activity is one of the efforts to improve farmer capacities. Howeverm the majority of mango farmers $(80 \%)$ in this study stated that they did not participated in extension activities related to mango farming (Table 3). In addition, farmers were not joined in farmer groups or organizations.

Table 3. Mango land mastery status and frequency following mango counseling in terms of land mastery area

\begin{tabular}{clcccc}
\hline & & \multicolumn{3}{c}{ Land Tenure } & \multirow{2}{*}{ Total (\%) } \\
\cline { 3 - 5 } & & Narrow & Medium & Large & \\
\hline Mango land tenure status (\%) & Belongs to & 39 & 20 & 9 & 68 \\
& Rent & 4 & 7 & 2 & 13 \\
& Belongs to and rent & 6 & 5 & 8 & 19 \\
Total (\%) & & 49 & 32 & 19 & 100 \\
Joining mango counseling (\%) & Never & 39 & 26 & 15 & 80 \\
& $1-2$ times & 10 & 6 & 4 & 20 \\
& & 49 & 32 & 20 & 100 \\
\hline
\end{tabular}


Although the selling price of mango, according to most farmers, was quite good, the price was not stable or fluctuating yet. Sometimes farmers benefit from high prices of mangoes, but when prices fall due starting the main harvest season, farmers will not benefit (Esperanza et al. 2018). The final market destination of farmers is also very limited, namely the contractor/broker/collector trader and the traditional market (Sari et al. 2019), so the mango farmers still have difficulty to sell their mangoes directly to modern market or export market. The dominance of ffly and yellow fly pests as well as rots disease on fruits was also obstcales on mango farming. The majority of farmers stated that the price of pesticides / chemical drugs was very expensive, so they could not afford to buy it. Therefore, they could not overseethe diseases. In addition, factors out of control such as unpredictable weather also triggered the emergence of pests (OPT). The limited mango processing industry a the research location caused the off-grade mango harvest of farmers could not be processed properly in order to provide additional income for farmers.

Nevertheless, there is hope that arises from each of those earlier problems, namely increased control of mango land, farmers' capital is sufficient, and farmers are interested in joining a farmer Group. Furthermore, the government policies related to the development of mango agribusiness can improve farmers' welfare, farmers' quality increases, products according to market demand in terms of quantity and quality, stable prices and profitable for farmers and the mango market is becoming wider including modern markets and export markets. Then with subsidized saprotan prices (fertilizers, pesticides / chemical drugs) mango plants become free from pests and diseases that lead to the availability of mango processing Industry. All of that will make the District of Cikedung itself and Indramayu Regency in general, truly deserve the nickname as the City of Mango so that it can be used as a city branding to attract local and foreign tourists.

Meanwhile, the possible side effects will occur such as change in land tenure increase from mango farming to others farming or outside of farming (Rachmah et al, 2019). Government grants in the form of capital are used for daily needs, loan money is used for daily needs and others, non-current capital loan repayments, loans in the form of capital are considered grants, land lease payments are not on time, grants are not targeted, too frequent extension activities make farmers saturated, farmers are not able to meet the quantity, quality, continuity of mangoes for export and modern markets, and the use of pesticides by farmers is increasingly dominan (Sulistyowati et al. 2015).

The various problems mentioned above are assumed to be able to be overcome properly if the government as a supporting institution actively participates to help farmers. Indirectly, the government involvement will later produce pros and cons and influence at the farm level as the recipient of the policy. The influence or impact of government participation on the development of mango agribusiness will vary. The Tinbergen model framework for research in the district of Cikedung is used to look at all the possibilities that will occur if the government provides policies related to increased mastery of mangoes based on the problems faced by farmers today.

Referring to Figure 3, it appears that there is a relationship in the model that will affect all the variables involved in - which include:

1) Policy instruments/tools, in the form of government policies related to the development of mango agribusiness that might be carried out as a basis or reference in achieving goals such as saprotan grants, seed grants, renting vacant land at low prices, as well as capital loans for farming activities.

2) The inhibiting factor is a fact or condition that is currently happening at the research location. Hence, it is assumed that government policy can solve the problem. Constraints / inhibiting factors include land area controlled by farmers, fluctuating selling price issues, limited government policies, and others.

3) Factors out of control are circumstances that cannot be predicted by farmers such as weather changes and fraud by individuals related to grants;

4) The phenomenon after the policy is an expectation to be achieved arising from the interaction between the inhibiting factors, factors outside the control, and policy instruments.

5) Variable objectives in the model are targets generally to be achieved from policy instruments as well as inhibiting factors and factors beyond control, namely in the form of development of mango agribusiness in terms of increasing mastery of mango farmer land.

6) Side effects are the possible impacts that will arise from the relationship between policy instruments, inhibiting factors, and factors beyond control.

7) The ultimate goal is the main or basic goal to be achieved and obtained from the general goal, namely an increase in land tenure for mango farmers in the District of Cikedung. 


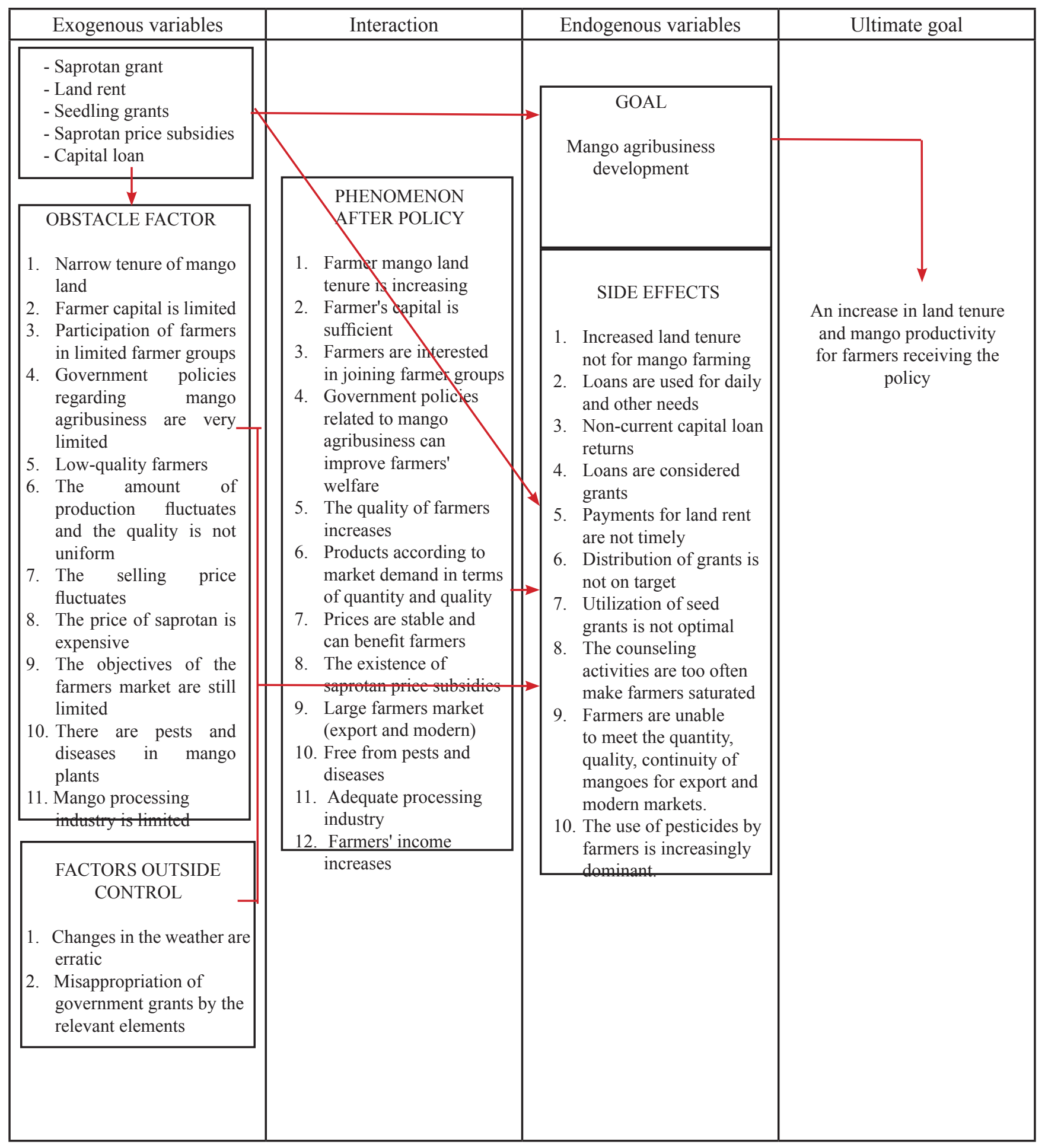

Figure 3. Simulation of government policies related to mango agribusiness development using the tinbergen model framework

\section{Managerial Implications}

Based on the simulation results of the Tinbergen model related to government policy, it can be concluded that various problems faced by farmers such as narrow control of mango land, limited capital, low quality human resources of farmers, to the price of expensive saprotans will be overcome properly if the government as a supporting institution actively participates in help farmers. Based on the findings of this study there are managerial implications for the government related to various problems faced by these farmers. Implications related to improving the quality of human resources and income of mango farmers can be done by the government through the local Agriculture and Extension Service by conducting technical training and 
guidance related to mango agribusiness to farmers in a gradual and continuous manner especially in postharvest handling. Implications related to increasing land tenure of mango farmers as a form of government contribution can be made by issuing regulations or policies related to the use of idle land in Indonesia. Utilization of idle land can be done with a rental system, but the rental price offered to farmers must be lower than the rental price of land on the market. Regulations related to subsidized saprotan prices are also needed by farmers so that mango crop maintenance activities can be optimized. Not only that, assistance in the form of capital loans and seeds requires strict control and supervision from the authorities so that the distribution of aid activities is on target, concrete, and relevant. Moreover, if added control and strict supervision from various parties, the distribution of assistance to farmers will be more effective.

\section{CONCLUSIONS AND RECOMMENDATIONS}

\section{Conclusions}

Farmers with narrow, medium and large land tenure have never received government contributions in the form of subsidized saprotan prices, saprotan grants, land rent, or capital loans for mango farming. However, if the government makes these contributions, it is likely that there will be an increase in land tenure as a form of developing the scale of mango farmer farming.

Mango agribusiness development policies that may be carried out to increase the area of land tenure so that it has an impact on increasing the number of mango yields namely agricultural production facilities grants, land rent, seed grants, saprotan price subsidies, and capital loans.

\section{Recommendations}

The quality of human resources and income from mango farming can be improved by holding counseling and training by the local Agriculture Office regarding mango agribusiness gradually and continuously, especially in post-harvest handling. The scale of farming of mango farmers can develop and increase with the contribution from the government both in the form of regulations related to saprotan price subsidies and programs and assistance such as capital loans, saprotan grants, to the rental of idle land at low prices.

\section{ACKNOWLEDGMENTS}

The author would like to thank all parties involved in this study including the Village Board of Cikedung Subdistrict in Indramayu Regency, farmer groups and member farmers as a source of information, as well as other parties. We would also like to thank the Higher Education Primary Research (PDUPT) DIKTI program that has funded our research and publications

\section{REFERENCES}

Alviany Y. 2013. Analisis manajemen risiko usahatani mangga di kabupaten indramayu, jawa barat (kasus: petani buah mangga di Desa Krasak, Kecamatan Jatibarang, Kabupaten Indramayu). [Skripsi]. Departemen Agribisnis, Fakultas Ekonomi dan Manajemen, Institut Pertanian Bogor.

Azizah MN, Rasmikayati E, Saefudin BR. 2019. Perilaku budidaya petani mangga dikaitkan dengan lembaga pemasarannya di Kecamatan Greged Kabupaten Cirebon. Jurnal Ilmiah Mahasiswa Agroinfo Galuh 5(1): 987-998. DOI: http://dx.doi.org/10.25157/jimag.v5i1.1447.

BPS. 2017. Provinsi Jawa Barat dalam Angka 2017. https://jabar.bps.go.id/publication/download. html [15 Feb 2019].

BPS Kabupaten Indramayu. 2017. Kabupaten Indramayu dalam Angka 2017. https:// indramayukab.bps.go.id/publication/download. html [15 Feb 2019].

Elfadina EA, Rasmikayati E, Saefudin BR. 2019. Analisis luas dan status penguasaan lahan petani mangga dikaitkan dengan perilaku agribisnisnya di Kecamatan Cikedung Kabupaten Indramayu. Jurnal Ilmiah Mahasiswa Agroinfo Galuh 6(1): 69-79. DOI: http://dx.doi.org/10.25157/jimag. v6i1.1376.

Esperanza D et al. 2018. Adaptation behavior of mango farmers to climate change. Jurnal Manajemen \& Agribisnis 15(3): 268. DOI: https://doi. org/10.17358/jma.15.3.268.

Farizal F. 2015. Dampak kebijakan pemerintah terhadap keuntungan dan keunggulan komparatif komoditas buah unggulan Jawa Barat. Accessed through: https://repository.ipb.ac.id/ handle/123456789/78261 [15 Feb 2019].

Friyatno S, Saptana S. 2017. Kinerja agribisnis komoditas pertanian: kemampuan penciptaan 
output, nilai tambah dan keterkaitan antar sektor (analisis komparasi IO tahun 2005 dan 2010). Jurnal Manajemen \& Agribisnis 14(3): 250. DOI: https://doi.org/10.17358/jma.14.3.250.

Hapsari H, Rasmikayati E, Saefudin BR. 2019. Karakteristik petani dan profil usahatani ubi jalar di Kecamatan Arjasari, Kabupaten Bandung. Sosiohumaniora 21(3): 247-255. DOI: https:// doi.org/10.24198/sosiohumaniora.v21i3.21288.

Iqbal M, Dalimi A. 2017. Kebijakan Pengembangan Agribisnis Kakao Melalui Prima Tani: Kasus Kabupaten Luwu, Provinsi Sulawesi Selatan.

Kusumo RAB et al. 2018. Faktor-Faktor yang mempengaruhi keputusan petani mangga dalam menggunakan teknologi off season di Kabupaten Cirebon. Mimbar Agribisnis: Jurnal Pemikiran Masyarakat Ilmiah Berwawasan Agribisnis 4(1): 57-69.

Pratiwi DE. 2013. Analisis Strategi Pemasaran Mangga Gedong Gincu Kabupaten Indramayu untuk Pusat Perbelanjaan di Kota Besar (Kasus CV Damardjati, Kecamatan Jatibarang, Kabupaten Indramayu) [Skripsi]. Bogor: Departemen Agribisnis, Fakultas Ekonomi dan Manajemen, Institut Pertanian Bogor.

Rachmah AD, Rasmikayati E, Saefudin BR. 2019. Factors related to continuation of mango cultivation. Jurnal Pertanian 10(2): 52-60. DOI: http://dx.doi.org/10.30997/jp.v10i2.1864.

Rachmat N. 2016. Profil Petani Cengkeh (Studi Kasus di Desa Kertamukti, Kecamatan Cikelet, Kabupaten Garut, Provinsi Jawa Barat). [Skripsi]. Jatinangor: Program Studi Agribisnis, Fakultas Pertanian, Universitas Padjadjaran.

Rasmikayati E, Saefudin BR. 2018. Analisis faktorfaktor yang mampu mendorong petani mangga untuk meningkatkan perilaku agribisnisnya pada era globalisasi. Paradigma Agribisnis 1(1):113.
Rasmikayati E, Saefudin BR. 2018. Confirmatory factor analysis: faktor-faktor penentu agribisnis mangga di Kabupaten Majalengka berdasarkan penguasaan lahannya. Jurnal Agribisnis Terpadu 4(1):100-109. DOI: http://dx.doi.org/10.33512/ jat.v11i1.5088.

Rasmikayati, E. Mukti, G. W. \& Saefudin, B. R. 2019. The determinant factors of the dynamics of agribusiness behavior of the mango farmers in Greged Sub District, Cirebon District. IOP Conference Series: Earth and Environmental Science 334(1): 012054. DOI: https://dx.doi. org/10.1088/1755-1315/334/1/012054.

Rasmikayati et al. 2018. Kajian potensi dan kendala dalam proses usahatani dan pemasaran mangga di Kabupaten Indramayu. Sosiohumaniora 20(3): 215-221. DOI: https://doi.org/10.24198/ sosiohumaniora.v20i3.15859.

Rasmikayati E, Sulistyowati L, Saefudin BR. 2017. Risiko produksi dan pemasaran terhadap pendapatan petani mangga: kelompok mana yang paling berisiko. Mimbar Agribisnis: Jurnal Pemikiran Masyarakat Ilmiah Berwawasan Agribisnis 3(2): 105-116. doi: http://dx.doi. org/10.25157/ma.v3i2.564.

Sari AF, Rasmikayati E, Saefudin BR. 2019. Behavioral dynamics of farmers and first buyer in marketing mangoes in Sedong District, Cirebon Regency, West Java. Agrifor 18(1): 63-72.

Sulistyowati L, Natawidjaja RS, Rahmat B. 2015. Adoption of technology and economics efficiency of the small-holder mango farmers in Indonesia. International Journal of Applied Business and Economic Research (Ijaber) 13(7): 4621-4645.

Pradipta A, Firdaus M. 2014. Posisi daya saing dan faktor-faktor yang memengaruhi ekspor buah-buahan Indonesia. Jurnal Manajemen \& Agribisnis 11(2):129-143. DOI: https://doi. org/10.17358/jma.11.2.129-143. 